\section{Performance of Aquaculture Effluent for Tomato Production in Outdoor Raised Beds}

\author{
D. Allen Pattillo ${ }^{1}$, Wheeler G. Foshee, $\mathrm{III}^{2}$, Eugene K. Blythe ${ }^{3}$, \\ Jeremy Pickens ${ }^{2}$, Daniel Wells ${ }^{2}$, Tyler A. Monday ${ }^{2}$, \\ and Terrill R. Hanson ${ }^{1}$
}

\begin{abstract}
ADDITIONAL INDEX WORDS. aquaponics, biofloc, fertigation, nile tilapia, Oreochromis
\end{abstract} niloticus, Solanum lycopersicum

SUMMARY. Raised bed production trials were conducted to evaluate the effectiveness of effluent from a biofloc-style recirculating aquaculture system producing nile tilapia (Oreochromis niloticus) as nutrient-rich irrigation water for fall 'Celebrity' tomato (Solanum lycopersicum) production. The objective of this study was to provide baseline vegetable production data and justification for using aquaculture effluent as a water and nutrient resource. The experiment was a split-plot, randomized block design with three treatments: aquaculture effluent, granular fertilizer, and fertigation. Tomato seeds were sown in June, transplanted in August, and grown until Oct. 2019 in nine replicated raised beds. Conventional field tomato production practices were followed throughout the trial, and data were collected for tomato fruit yield, market quality, size, leaf greenness (SPAD), and foliar nutrient analysis. Fruit yield was similar between fertigated and aquaculture effluent treatments, with granular fertilizer resulting in yield that was significantly lower $(P \leq \mathbf{0 . 0 3 3})$. SPAD measurements were similar among treatments. All nutrients met or exceeded sufficiency ranges. Foliar nutrient analysis revealed no significant difference for nitrogen, phosphorus, potassium, magnesium, calcium, boron, zinc, manganese, and iron among treatments. Sulfur and copper levels were significantly lower $(P<0.05)$ with aquaculture effluent treatment as compared with the granular and fertigated treatments. Overall, tomato production using aquaculture effluent as a water and nutrient supplement produced similar yields to commercial practices, making it potentially viable for producers.

A quaculture is under great scrutiny as a source of nutrient pollution, specifically as a driver of eutrophication, excessive aquatic plant growth, fish kills, high biological oxygen demands, and harmful algal blooms in natural water bodies (Boyd and Hargreaves, 2004; Boyd and Tucker, 1998). Fish waste contains organic nutrients, with nitrogen $(\mathrm{N})$ being of primary importance, with $70 \%$ to $80 \%$ released as ammonia nitrogen $\left(\mathrm{NH}_{3} / \mathrm{NH}_{4}{ }^{+}\right)$ (Graber and Junge, 2009). Aquaculture production systems are typically designed to process waste. For instance, in indoor recirculating systems, solid waste can be removed via filtration, and toxic ammonia can be transformed into nontoxic nitrate through a biological filter (Pattillo, 2017b; Timmons and Ebeling, 2013). Discharged waste remains a serious environmental concern (Palada et al., 1999), especially for concentrated aquatic animal production facilities (U.S. Environmental Protection Agency, 2020). The regulation of nutrient effluent is a major issue restricting the growth of the aquaculture industry in the United States (Yeo et al., 2004). Permit requirements for $\mathrm{N}$ and phosphorous as well as associated mitigation costs can be cost-prohibitive. Discharge permits stipulate water volume and concentrations of certain nutrients like $\mathrm{N}$ and phosphorus $(\mathrm{P})$, and managing these nutrients is costly for commercial producers. Aquaculture is expected to increase substantially [Food and Agriculture Organization of the United Nations (FAO), 2018], necessitating cost-effective, sustainable effluent mitigation strategies (Weeks, 2013). Vegetable crop production is an attractive use for aquaculture effluent due to resource efficiency and reduced need for expensive water treatment (Palada et al., 1999; Pattillo, 2017a).

The efficacy of aquaculture effluent for supplying required plant nutrients has been studied in the field of aquaponics (Blanchard et al., 2020; Danaher et al., 2013, 2016; Graber and Junge, 2009; Khater et al., 2015; Monsees et al., 2017; Nozzi et al., 2018; Pattillo, 2017a; Pickens, 2015; Rafiee and Saad, 2005; Rakocy et al., 2004, 2006; Tyson et al., 2011). For example, Mariscal-Lagarda et al. (2012) reported similar production between the hydroponic solution and low-salinity shrimp [whiteleg shrimp (Litopenaeus vannamei)] aquaculture effluent for growing beefsteak-type tomato (Solanum lycopersicum). The dissolved nutrient concentrations vary based on aquaculture production practices, feed, and supplement inputs, culture temperature, and species grown (Pattillo, 2017a; Pickens, 2015). Many required nutrients are sufficient while others are not, depending on the requirements of the plant being grown (Hochmuth and Hochmuth, 2018; Nozzi et al., 2018; Pattillo, 2017a; Pickens, 2015). Commonly, aquaponics is practiced under greenhouse conditions to control temperature, humidity, pests, and weather conditions (Pickens and Danaher, 2016). However, the cost

\begin{tabular}{llll}
\hline $\begin{array}{l}\text { Units } \\
\text { To convert U.S. to SI, } \\
\text { multiply by }\end{array}$ & U.S. unit & SI unit & $\begin{array}{l}\text { To convert SI to U.S., } \\
\text { multiply by }\end{array}$ \\
\hline 0.4047 & acre $(\mathrm{s})$ & $\mathrm{ha}$ & 2.4711 \\
0.3048 & $\mathrm{ft}$ & $\mathrm{m}$ & 3.2808 \\
0.0929 & $\mathrm{ft}^{2}$ & $\mathrm{~m}^{2}$ & 10.7639 \\
0.0283 & $\mathrm{ft}^{3}$ & $\mathrm{~m}^{3}$ & 35.3147 \\
3.7854 & gal & $\mathrm{L}$ & 0.2642 \\
0.7457 & horsepower & $\mathrm{kJ} \cdot \mathrm{s}^{-1}$ & 1.3410 \\
0.7457 & horsepower & $\mathrm{kW}$ & 1.3410 \\
2.54 & inch(es) & $\mathrm{cm}$ & 0.3937 \\
25.4 & inch(es) & $\mathrm{mm}$ & 0.0394 \\
0.4536 & lb & $\mathrm{kg}$ & 2.2046 \\
1.1209 & $\mathrm{lb} / \mathrm{acre}$ & $\mathrm{kg} \cdot \mathrm{ha}^{-1}$ & 0.8922 \\
1 & $\mathrm{meq} / 100 \mathrm{~g}$ & $\mathrm{cmol} \cdot \mathrm{kg}^{-1}$ & 1 \\
0.0254 & $\mathrm{mil}(\mathrm{s})$ & $\mathrm{mm}$ & 39.3701 \\
1 & $\mathrm{mmho} / \mathrm{cm}$ & $\mathrm{mS} \cdot \mathrm{cm}^{-1}$ & 1 \\
28.3495 & $\mathrm{oz}$ & $\mathrm{g}$ & 0.0353 \\
1 & $\mathrm{ppm}$ & $\mathrm{mg} \cdot \mathrm{kg}^{-1}$ & 1 \\
1 & $\mathrm{ppm}$ & $\mathrm{mg} \cdot \mathrm{L}^{-1}$ & 1 \\
$\left({ }^{\circ} \mathrm{F}-32\right) \div 1.8$ & ${ }^{\circ} \mathrm{F}$ & ${ }^{\circ} \mathrm{C}$ & $\left({ }^{\circ} \mathrm{C} \times 1.8\right)+32$ \\
& & &
\end{tabular}


of infrastructure and energy with greenhouse production are higher, and seasonal competition from field crops make profitability difficult (Cantliffe and Vansickle, 2001; Engindeniz and Gül, 2009; Jovicich et al., 2005, 2007; Pickens and Danaher, 2016; Pickens et al., 2016). Thus, developing a production system that can take advantage of aquaculture effluent under field production conditions during peak season could make this technology more economically viable for farmers (Cantliffe and Vansickle, 2001; Engindeniz and Gül, 2009; Fern, 2014).

Aquaculture effluent has demonstrated its ability to supply the nutrient and water demands of horticultural crops under field conditions, although peer-reviewed literature on this topic is limited. Castro et al. (2006) grew cherry tomato using aquaculture effluent compared with well water as an irrigation water source with several organic nutrient amendments, demonstrating increased production with aquaculture effluent. Additionally, they realized the greatest gross and net income, and rate of return when irrigating with aquaculture effluent. Palada et al. (1999) evaluated field-grown bell pepper (Capsicum annumm) using aquaculture effluent and sludge compared with conventional

Received for publication 24 May 2020. Accepted for publication 27 June 2020.

Published online 14 August 2020.

${ }^{1}$ School of Fisheries, Aquaculture, and Aquatic Sciences, Auburn University, 203 Swingle Hall, Auburn, AL 36849

${ }^{2}$ Department of Horticulture, Auburn University, 101 Funchess Hall, Auburn, AL 36849

${ }^{3}$ College of Agriculture, Auburn University, 167A Funchess Hall, Auburn, AL 36849

Thank you to reviewers Luke Roy and David Cline and the Auburn Aquaponics crew: Mollie Smith, Alexandre Sousa, Kyle Hensarling, Caroline Blanchard, Rohit Kalvakaalva, Emmanuel Ayipio, Josh Marcus, Nick Burgess, Nate Wallace-Springer, Jenny Dorick, Ana Gabriela Itokazu Canzian da Silva, Andrew Palmer, Jim, and Gift who helped make this project a success.

D.A.P. is a $\mathrm{PhD}$ candidate

W.G.F. is an Associate Professor.

E.K.B. is a Director of Statistics, Teaching, and Consulting.

J.P. is an Assistant Research and Extension Professor. D.W. is an Associate Professor.

T.A.M is a Research Fellow.

T.R.H. is a Professor and Extension Specialist.

W.G.F. is the corresponding author. E-mail: foshewg@auburn.edu.

This is an open access article distributed under the $\mathrm{CC}$ BY-NC-ND license (https://creativecommons.org/ licenses/by-nc-nd/4.0/).

https://doi.org/10.21273/HORTTECH04655-20 methods, finding comparable and even improved yields using aquaculture effluent. The present study evaluates the effectiveness of aquaculture effluent as a nutrient-rich irrigation water source compared with conventional methods for fall 'Celebrity' tomato production in raised beds.

\section{Materials and methods}

STUdy LOCATION. This study was conducted from June through Oct. 2019 at the Auburn University, E.W. Shell Fisheries Research Station, located in Auburn, AL (lat. $32.648953^{\circ} \mathrm{N}$, long. $\left.85.486828^{\circ} \mathrm{W}\right)$.

Treatments. This study compares three different nutrient management regimes to produce 'Celebrity' tomato in raised beds. The treatments were: 1) conventional fertigation with water-soluble potassium nitrate $\left(\mathrm{KNO}_{3}\right)$ and calcium nitrate $\left[\mathrm{Ca}\left(\mathrm{NO}_{3}\right)_{2}\right]$ and pond water; 2) conventional granular fertilizer application with drip-irrigated pond water; and 3) aquaculture effluent (water from a biofloc-style recirculating aquaculture system) with the water source, pond water.

RAISED BED SOIL PREPARATION. Weeds were controlled with recommended practices by Sparks and Riley (2019). Each raised bed received a preapplication of granular fertilizer that was incorporated into the soil based on the soil test results and recommendations for tomato production such that $50 \%$ of the crop's $\mathrm{N}$ and potassium $(\mathrm{K})$ demands and $100 \%$ of the $P$, sulfur (S), boron (B), calcium $(\mathrm{Ca})$, magnesium $(\mathrm{Mg})$, manganese $(\mathrm{Mn})$, zinc $(\mathrm{Zn})$, and chlorine (Cl) demands were provided before transplant (Kemble et al., 2004). Recommended tomato fertility recommendations under field conditions are 150 to $180 \mathrm{lb} / \mathrm{acre}$ of N; $200 \mathrm{lb} /$ acre phosphorus pentoxide $\left(\mathrm{P}_{2} \mathrm{O}_{5}\right)$; and $250 \mathrm{lb} /$ acre potassium oxide $\left(\mathrm{K}_{2} \mathrm{O}\right)$ (Kemble et al., 2004). Commercially available granular fertilizers were applied as urea $\left[\mathrm{CH}_{4} \mathrm{~N}_{2} \mathrm{O}(42 \mathrm{~N}-0 \mathrm{P}-0 \mathrm{~K})\right]$, triple superphosphate $\left[\mathrm{Ca}\left(\mathrm{H}_{2} \mathrm{PO}_{4}\right)_{2} \cdot \mathrm{H}_{2} \mathrm{O} \quad(0 \mathrm{~N}-\right.$ $19.7 \mathrm{P}-0 \mathrm{~K})]$, muriate of potash $[\mathrm{KCl}$ $(0 \mathrm{~N}-0 \mathrm{P}-49.8 \mathrm{~K})], 10 \%$ boron, pelletized dolomitic lime $\left[\mathrm{Ca} \cdot \mathrm{Mg}\left(\mathrm{CO}_{3}\right)_{2}\right]$, and a complete fertilizer $(10 \mathrm{~N}-4.4 \mathrm{P}-8.3 \mathrm{~K}-$ $12 S$ ) with $2 \% \mathrm{Mg}, 0.07 \% \mathrm{~B}, 0.25 \% \mathrm{Mn}$, $0.25 \% \mathrm{Zn}$, and less than $1 \% \mathrm{Cl}$ (AllPurpose Fertilizer; Southern Ag, Hendersonville, NC).

Nutrient management. The remaining $50 \%$ of the $\mathrm{N}$ and $\mathrm{K}$ requirements were provided according to the experimental treatment. The granular fertilizer treatment received urea and muriate of potash as a second banded application incorporated into the soil midway through the production trial. The fertigated treatment received an alternating schedule of $\mathrm{KNO}_{3}$ and $\mathrm{Ca}\left(\mathrm{NO}_{3}\right)_{2}$ on a schedule adapted to the growth of the plants based on industry practices (Kemble et al., 2004; University of Georgia, 2017). Aquaculture effluent used for the third treatment was collected from a biofloc-style recirculating aquaculture system producing nile tilapia (Oreochromis niloticus). Nitrate and other nutrients came from the fish feed, while $\mathrm{K}$ and $\mathrm{Ca}$ were dissolved in the fish culture water as $\mathrm{KCl}$ and calcium hydroxide $\left[\mathrm{Ca}(\mathrm{OH})_{2}\right]$ as part of the regular fish production practices.

IrRIgation. For the conventional fertigation and granular fertilizer treatments, an irrigation system was constructed, including a 300 -gal pond water reservoir, 1.5-horsepower irrigation pump (Red Lion, Ft. Wayne, IN), pump timer, plumbing system, 1:100 fertilizer injector (Chemilizer; Hydro Systems Co., Cincinnati, $\mathrm{OH}$ ) and cumulative flow meters (Hersey-Sparling Meter Co., Dedham, MA and Rockwell International, Pittsburgh, PA). The aquaculture effluent treatment water was taken from the second clarifier tank of the aquaculture system. The irrigation pumps were set on a single shutoff switch and engaged as needed based on plant appearance and precipitation. The water was delivered to the raised beds through a 0.75 -inchdiameter, black polyethylene irrigation hose with 0.25 -inch-diameter microtubing that had $1-$ gal/h anticlog drip emitters (Bowsmith, Exeter, CA) installed for each plant.

RAISED BEDS. A series of nine raised beds (Fig. 1A) were constructed, measuring $4 \mathrm{ft}$ wide $\times 20 \mathrm{ft}$ long $\times 1 \mathrm{ft}$ tall and filled with loamy sand soil $($ mean $\pm \mathrm{SD})(83.8 \% \pm 3.6 \%$ sand, $6.1 \% \pm 2.4 \%$ silt, $10.1 \% \pm 2.7 \%$ clay), with mean cation exchange capacity (CEC) of $6.6 \pm 1.9 \mathrm{meq} /$ $100 \mathrm{~g}$, organic matter of $3.29 \% \pm$ $1.07 \%$, and soil $\mathrm{pH}$ of $6.3 \pm 0.3$. Each raised bed was assigned to a block design for statistical analysis based on location and soil texture. Three replicates of each of the three treatments 


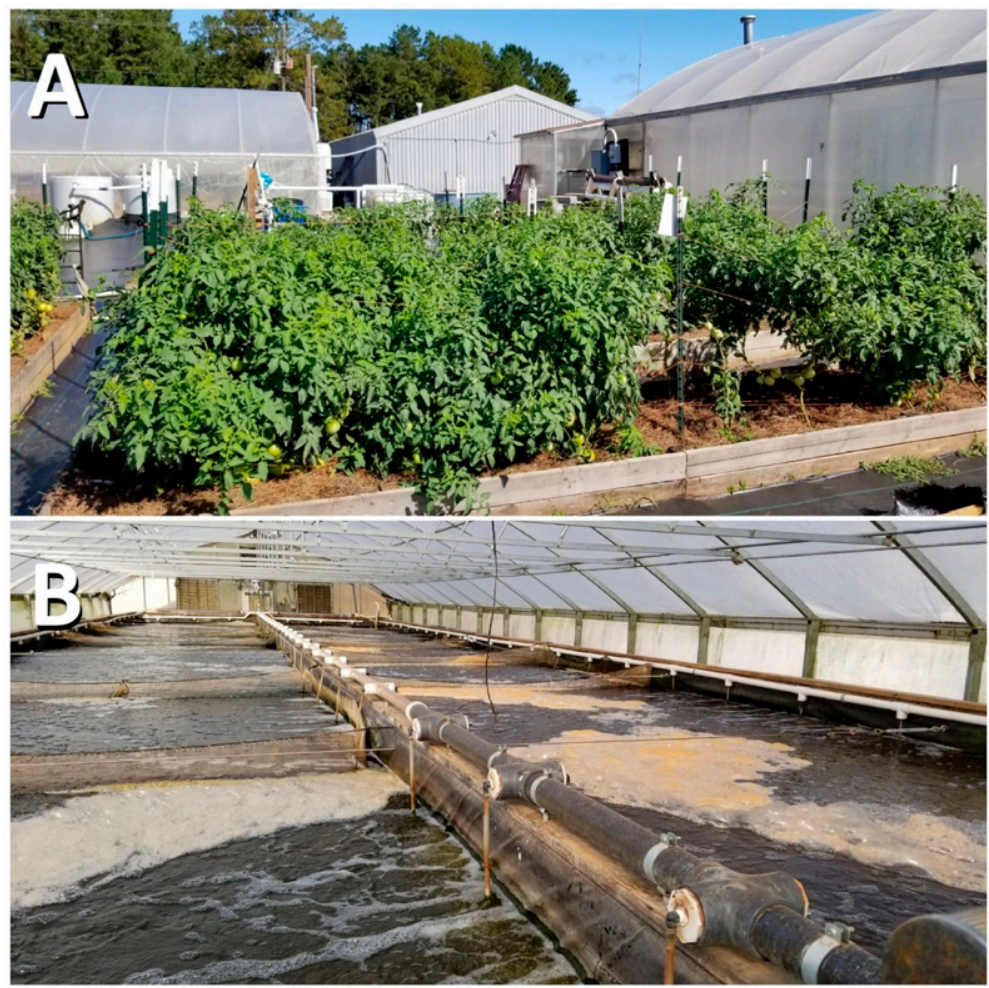

Fig. 1. Raised beds for 'Celebrity' tomato production (A) and biofloc-style recirculating aquaculture system for nile tilapia production (B).

were randomly assigned to each of the three blocks.

Fish pRODUCTION. A bioflocstyle production system was used to produce nile tilapia in a $30 \times 96-\mathrm{ft}$ double-layered 6-mil polyethylenecovered greenhouse with two 27,000-gal rectangular tanks (Fig. 1B). The culture water was vigorously aerated using rubber diffuser hose, which runs along the perimeter of each fish tank powered by two, 1.5horsepower blowers (Sweetwater Blowers; Pentair Aquatic Eco-Systems, Apopka, FL). About 5\% of the tank water volume of $1347 \mathrm{gal}$ is replaced daily by incoming pond water for irrigation needs in the overall aquaponics operation. The single fish tank used in this experiment was stocked with $\approx 6000$ fish $\left(\approx 60 \mathrm{fish} / \mathrm{m}^{3}\right)$ of varying sizes from fry $(\mathrm{lg})$ to harvestable adults $(750 \mathrm{~g})$ and the fish were fed twice daily with high-protein, pelleted, complete nutrition, soybean (Glycine max)-based 4010 (3 mm diameter; $40 \%$ protein, $10 \%$ lipid) or $3606(5 \mathrm{~mm}$ diameter; $36 \%$ protein and $6 \%$ lipid) fish feed (Triton; Cargill, Franklinton, LA) depending on the fish size. Water quality parameters such as temperature and dissolved oxygen
(Handy Polaris; OxyGuard, Farum, Denmark), pH (HI9813-5 Portable $\mathrm{pH} / \mathrm{EC} / \mathrm{TDS}$ Meter; Hanna Instruments, Woonsocket, RI), and total ammonia nitrogen [TAN (Ammonia Alert; Seachem Laboratories, Madison, GA)] were measured daily and maintained at proper levels for fish and plant culture. Water exchange and additions of $\mathrm{Ca}(\mathrm{OH})_{2}$ and $\mathrm{KCl}$ were carried out as needed (Popma and Masser, 1999).

Aquaculture effluent. Fish culture water moved via airlift pump (Reinemann et al., 1990; Timmons and Ebeling, 2013) from the fish tank and passed through two, 400-gal cone-bottom clarifier tanks in series to settle large solids. The clarifier tank flow rate was 2 to $5 \mathrm{gal} / \mathrm{min}$, creating a hydraulic residence time of 80 to $200 \mathrm{~min}$, which allows at least $50 \%$ of the suspended solids to settle and be removed from the culture water as sludge (Blanchard et al., 2020; Timmons and Ebeling, 2013). The clarified water was returned to the fish tank via airlift pump. The aquaculture effluent water used for plant production was sourced from the second clarifier. The concentrated sludge that settles into the bottom of the conical tanks was discharged once per day, producing 5 to 40 gal of sludge depending on feeding rate (data not reported). Water was collected from the drip emitters periodically to assess the composition of the aquaculture effluent. Nitrate, $\mathrm{pH}$, and electrical conductivity (EC) were measured with probes (LAQUAtwin, Horiba, UK) specific to each parameter.

Tomato production. 'Celebrity' tomato seeds, chosen for their yield potential (Boyhan et al., 2014), were sown in a germination mix (ProMix BX Starter Mix; Premier Tech Horticulture, Quakertown, $\mathrm{PA}$ ) in 50 cell-count trays on 21 June 2019. Seedlings were grown under greenhouse conditions and watered as needed with $14 \mathrm{~N}-2.2 \mathrm{P}-31.5 \mathrm{~K}$ water-soluble fertilizer [Jack's Professional LX; J.R. Peters, Allentown, PA] water for 6 weeks, then potted up to 4 -inch square pots on 31 July 2019. Plants were hardened off before transplant into raised beds on 13 Aug. 2019. Tomato seedlings were transplanted at 16 plants per $80 \mathrm{ft}^{2}$ raised bed, with 30 -inch spacing in the row, 24 inches between rows, and $3 \mathrm{ft}$ between raised beds (estimated 4329 plants/acre). Pine straw mulch was applied at a 4-inch depth (two bales per raised bed) (Tindall et al., 1991). Plants were trellised using a variation of the Florida weave method, with suckers and excess foliage pruned as needed according to commercial practices (Kemble et al., 2004; University of Georgia, 2017). Carbaryl (Sevin; GardenTech, Palatine, IL) chlorothalonil (Daconil, GardenTech), and myclobutanil (Immunox; Spectracide, Middleton, WI) were applied according to manufacturer specifications as needed (every 2 to 3 weeks). Tomato harvest was initiated when tomatoes showed signs of ripeness on 10 Oct. 2019 and occurred twice weekly until final harvest on 28 Oct. 2019 due to impending freezing weather.

Data collection. Tomatoes were harvested twice weekly at the breaker-stage or as significant damage was observed (i.e., pest and cracking damage). At final harvest, all tomatoes were graded for size and quality, enumerated, and weighed. Grading categories included marketable (ripe, breaker, and green) and unmarketable (damaged and undersized) (U.S. Department of Agriculture, 1997). Marketable size was assessed using 
a 6-cm-diameter ring as a minimum marketable fruit diameter (Boyhan et al., 2014). Additionally, leaf greenness [relative chlorophyll content (SPAD)] measurements and foliar nutrient analysis data were collected (Nemeskéri et al., 2019). Leaf greenness, a surrogate measure for chlorophyll content, was assessed using a SPAD meter (SPAD 502 Plus Chlorophyll Meter; Spectrum Technologies, Aurora, IL) by clamping the meter onto multiple locations of the fifth leaflet from the growing tip to get an average reading on four plants per raised bed. Twenty to 25 newly matured leaflets (fourth from growing tip) were collected in duplicate per raised bed for foliar nutrient analysis of $\mathrm{N}, \mathrm{P}, \mathrm{K}, \mathrm{Mg}, \mathrm{Ca}, \mathrm{S}, \mathrm{B}, \mathrm{Zn}, \mathrm{Mn}$, $\mathrm{Cu}$, and $\mathrm{Fe}$, which was conducted by Waters Laboratory (Camilla, GA).

Statistical analysis. Data were analyzed with generalized linear models using the GLIMMIX procedure (SAS version 9.2; SAS Institute, Cary, NC) with the normal distribution and identity link function for fruit yield by weight, individual fruit size, SPAD, and foliar analysis; and negative binomial distribution and log link function for fruit counts and percentages of marketable and nonmarketable yield. Block and location were included in the models as random factors. East and west location factors were not significant; therefore, levels within main effects were examined. Post-hoc tests for differences among means were done using the Holm-Tukey method ( $\alpha=0.05)$.

\section{Results and discussion}

AQuaculture efFluent CHARACTERISTICS. The fish culture water temperature (mean \pm SD) $\left(84.2 \pm 3.2^{\circ} \mathrm{F}\right)$, dissolved oxygen $\left(5.3 \pm 1.0 \mathrm{mg} \cdot \mathrm{L}^{-1}\right), \mathrm{pH}(6.2 \pm 0.5)$, and ammonia disk readings were at safe levels for tilapia production throughout the culture period (Hargreaves and Tucker 2004; Popma and Masser, 1999). Overall pH was 6.6 and EC was $0.97 \mathrm{mS} \cdot \mathrm{cm}^{-1}$ (Table 1 ).

The Extension of the University of Georgia (2017) recommends tomato production in well-drained, sandy loam, loam, or clay loam soil with a $\mathrm{pH}$ of 6.0 to 6.8 . The average soil type in this study was loamy sand with a $\mathrm{pH}$ of 6.3 . For aquaculture effluent, the overall $\mathrm{pH}$ was 6.6 and the $\mathrm{EC}$ was $0.97 \mathrm{mS} \cdot \mathrm{cm}^{-1}$ (Table 1 ), which is similar to the $\mathrm{pH} 6.7$ reported by Pickens (2015), but different from the suggested $\mathrm{pH}$ of 6.0 6.5 and EC of 2.5-3.5 mmho/cm for hydroponic crop production (Resh, 2013). The nitrate, $\mathrm{pH}$, and EC levels collected from the drip emitters fluctuated over the production period (Table 1) due to variations in sampling location, water exchange, irrigation timing and duration, and fish feeding rates throughout the aquaponics operation. No negative impacts of $\mathrm{pH}$ or $\mathrm{EC}$ on growth were observed.

Generally, fish feed contains about $6 \%$ to $8 \%$ organic $\mathrm{N}$ and $1.15 \%$ organic P by weight, of which $15 \%$ to $20 \% \mathrm{~N}$ and $50 \% \mathrm{P}$ are retained in the fish, $60 \%$ to $86 \% \mathrm{~N}$ and $30 \% \mathrm{P}$ are dissolved in the water, and $6 \%$ to $15 \% \mathrm{~N}$ and $20 \% \mathrm{P}$ are deposited as solid particulate (D'orbcastel and Blancheton, 2006). Cumulative fish feed usage for the production period was $1053.5 \mathrm{lb}$ of 3606 feed $(6.513 \%$ $\mathrm{N}, 1.211 \% \mathrm{P})$ and $1404.5 \mathrm{lb}$ of 4010 feed $(6.95 \% \mathrm{~N}, 1.203 \% \mathrm{P})$. Total water usage for the fish culture tank for the study period was $126,460 \mathrm{gal}$, or $1664 \mathrm{gal} / \mathrm{d}$, which was $6.2 \%$ water exchange per day. The equivalent nutrient applied to the culture water from the fish feed were $166.2 \mathrm{lb}$ of $\mathrm{N}$ and $29.7 \mathrm{lb}$ of $\mathrm{P}$. The fish culture activity increased the nutrient content of the pond source water for $\mathrm{NO}_{3}-\mathrm{N}$

Table 1. Average water quality parameters of aquaculture effluent collected from drip emitters used for irrigation of 'Celebrity' tomatoes grown in raised beds.

\begin{tabular}{lccc}
\hline Time after transplant $(\mathbf{d})^{\mathbf{z}}$ & NO3-N $\left(\mathbf{m g} \cdot \mathbf{L}^{-\mathbf{1}}\right)^{\mathbf{y}}$ & $\mathrm{pH}$ & $\mathrm{EC}\left(\mathbf{m S} \cdot \mathrm{cm}^{-\mathbf{1}}\right)^{\mathbf{x}}$ \\
\hline 34 & 81.4 & 6.9 & 1.06 \\
48 & 112.0 & 6.7 & 0.84 \\
58 & 114.8 & 6.3 & 0.88 \\
65 & 100.1 & 6.6 & 1.09 \\
Overall $($ mean \pm SD) & $102.1 \pm 17.3$ & $6.6 \pm 0.2$ & $0.97 \pm 0.11$ \\
\hline
\end{tabular}

${ }^{\mathrm{z}}$ Transplant date 13 Aug. 2019.

${ }^{y}$ Nitrate-nitrogen; $1 \mathrm{mg} \cdot \mathrm{L}^{-1}=1 \mathrm{ppm}$

${ }^{\mathrm{x}}$ Electrical conductivity; $1 \mathrm{mS} \cdot \mathrm{cm}^{-1}=1 \mathrm{mmho} / \mathrm{cm}$. from $($ mean $\pm \mathrm{SD}) 1.1 \pm 0.3 \mathrm{mg} \cdot \mathrm{L}^{-1}$ to $72.3 \pm 33.1 \mathrm{mg} \cdot \mathrm{L}^{-1}, \mathrm{PO}_{4}-\mathrm{P}$ from $0.0 \pm$ $0.0 \mathrm{mg} \cdot \mathrm{L}^{-1}$ to $12.5 \pm 3.6 \mathrm{mg} \cdot \mathrm{L}^{-1}$, and $\mathrm{SO}_{4}-\mathrm{S}$ from $1.5 \pm 0.2 \mathrm{mg} \cdot \mathrm{L}^{-1}$ to $8.3 \pm$ $2.3 \mathrm{mg} \cdot \mathrm{L}^{-1}$ in aquaculture effluent collected from the clarifier. Nitrate levels collected from the clarifier were generally lower than those collected from the emitters. Aquaculture effluent nutrient levels in $\mathrm{mg} \cdot \mathrm{L}^{-1}$ (mean \pm SD) for May to July 2019 were $99.4 \pm$ $9.2(\mathrm{~N}), 11.7 \pm 1.3(\mathrm{P}), 134.6 \pm 33.1$ $(\mathrm{K}), 26.4 \pm 5.2(\mathrm{Mg}), 113.2 \pm 5.8$ (Ca), $8.3 \pm 2.3(\mathrm{~S}), 0.2 \pm 0.0(\mathrm{Mn})$, and $0.1 \pm 0.0(\mathrm{~B}, \mathrm{Zn}, \mathrm{Fe}$, and $\mathrm{Cu})$. Due to plumbing failures that caused major water leaks outside the raised beds and perceived inaccuracies in the cumulative water meter readings, the data for irrigation water usage is not presented. However, pre-experiment calibration of the drip emitter output suggests that the water delivery to each treatment was likely not significantly different.

Blanchard et al. (2020) evaluated cucumber production using aquaculture effluent in spring and summer in the months before this experiment. Average concentrations were 93 $\mathrm{mg} \cdot \mathrm{L}^{-1} \mathrm{~N}, 14.3 \mathrm{mg} \cdot \mathrm{L}^{-1} \mathrm{P}, 98.1$ $\mathrm{mg} \cdot \mathrm{L}^{-1} \mathrm{~K}, 115 \mathrm{mg} \cdot \mathrm{L}^{-1} \mathrm{Ca}$, and 29 $\mathrm{mg} \cdot \mathrm{L}^{-1} \mathrm{Mg}$. It is noteworthy that although the reported concentration of macronutrients and micronutrients in the aquaculture effluent water were well below the recommended levels for hydroponic solutions (Resh, 2013), the foliar analysis indicated that the concentration of all the nutrients was well above the sufficiency range recommendations (Blanchard et al., 2020). The mechanisms involved in nutrient uptake and availability at different concentrations and in different systems is a topic of debate in aquaponics but may relate to the continuous supply of organic and mineralized nutrients (Rakocy et al., 2006). Pickens (2015) described nutrient concentrations using the same culture system with a $<1 \%$ daily water exchange rate, providing ranges for $\mathrm{NO}_{3}-\mathrm{N}\left(400 \pm 62.3 \mathrm{mg} \cdot \mathrm{L}^{-1} ; 33 \mathrm{l}\right.$ $\left.\mathrm{mg} \cdot \mathrm{L}^{-1}\right), \mathrm{PO}_{4}-\mathrm{P}\left(3.3 \pm 0.98 \mathrm{mg} \cdot \mathrm{L}^{-1}\right)$, $\mathrm{PO}_{4}\left(46.7 \mathrm{mg} \cdot \mathrm{L}^{-1}\right), \mathrm{K}^{+}(170 \pm 14.1$ $\left.\mathrm{mg} \cdot \mathrm{L}^{-1} ; 239 \mathrm{mg} \cdot \mathrm{L}^{-1}\right), \mathrm{Ca}^{2+}(418 \pm 85$ $\left.\mathrm{mg} \cdot \mathrm{L}^{-1}\right)$, and $\mathrm{Mg}^{2+}(125 \pm 24.3$ $\left.\mathrm{mg} \cdot \mathrm{L}^{-1}\right)$, which fluctuated depending on management practices and time of year. Danaher et al. (2016) performed experiments using dewatered aquaculture effluent sludge from the 
same system and reported chemical concentrations for $\mathrm{NH}_{4}-\mathrm{N}$ (129.8 $\left.\mathrm{mg} \cdot \mathrm{L}^{-1}\right), \quad \mathrm{NO}_{3}-\mathrm{N}\left(0.8 \mathrm{mg} \cdot \mathrm{L}^{-1}\right), \quad \mathrm{P}$ $\left(70.2 \mathrm{mg} \cdot \mathrm{L}^{-1}\right), \mathrm{K}\left(204.5 \mathrm{mg} \cdot \mathrm{L}^{-1}\right)$, $\mathrm{Ca}\left(83.6 \mathrm{mg} \cdot \mathrm{L}^{-1}\right), \mathrm{Mg}\left(51.6 \mathrm{mg} \cdot \mathrm{L}^{-1}\right)$, $\mathrm{S}\left(111.9 \mathrm{mg} \cdot \mathrm{L}^{-1}\right), \mathrm{B}\left(0.13 \mathrm{mg} \cdot \mathrm{L}^{-1}\right), \mathrm{Fe}$ $\left(0.70 \mathrm{mg} \cdot \mathrm{L}^{-1}\right), \mathrm{Mn}\left(0.21 \mathrm{mg} \cdot \mathrm{L}^{-1}\right)$, and $\mathrm{Zn}\left(0.83 \mathrm{mg} \cdot \mathrm{L}^{-1}\right)$. The sludge generated during this experiment is an additional nutrient resource to evaluate in future research that may improve the yield and sustainability of the overall operation.

Fruit YIELd AND QuAlity. Average cumulative fruit yield per plant by weight (Table 2) was significantly higher in the aquaculture effluent [10.4 lb/plant, $45,011 \mathrm{lb} /$ acre $(P=$ $0.018)]$ and fertigation $[10.0 \mathrm{lb} /$ plant, $43,290 \mathrm{lb} /$ acre $(P=0.033)]$ treatments, compared with the granular fertilizer (7.6 lb/plant, 32,900 lb/acre) treatment. The marketable fruit yield by weight was significantly higher in the aquaculture effluent treatment $[5.1 \mathrm{lb} /$ plant $(P=$ $0.039)$ ] than the granular treatment (3.2 lb/plant), but neither were significantly different from the fertigation treatment $(4.2 \mathrm{lb} /$ plant) (Table 2 ). The nonmarketable fruit yield by weight and proportions of marketable and nonmarketable fruit were not significantly different (Table 2). Total fruit yields obtained in this study would be equivalent to 45,011 , 43,290 , and $32,900 \mathrm{lb} /$ acre for aquaculture effluent, fertigation, and granular fertilizer, respectively. The minimum average marketable field tomato yield using plastic mulch and drip irrigation is $\approx 37,500 \mathrm{lb} /$ acre at commercial densities of 4800 plants/ acre (University of Georgia, 2017). Tindall et al. (1991) reported 'Celebrity' tomato yield ranging from 35,680 to $89,200 \mathrm{lb} /$ acre. Boyhan et al. (2014) reported early marketable yield and total marketable yields for 'Celebrity' tomato of 17,939 and $33,574 \mathrm{lb} /$ acre respectively, under organic production conditions, with 205,216 fruit/acre at an average fruit size of $167 \mathrm{~g}$. Individual fruit weights in this study were not significantly different among treatments, with average marketable fruit sizes of (mean \pm SE) $147.3 \pm 4.0,147.5 \pm 4.0$, and $141.5 \pm 4.0 \mathrm{~g}$ for aquaculture effluent, fertigated, and granular fertilizer treatments, respectively.

Average cumulative fruit count for aquaculture effluent $(41.0 \pm 2.6$ fruit/plant) and fertigation (41.2 \pm 2.6 fruit/plant) were not significantly different $(P=0.065$ and 0.059 , respectively) from granular fertilizer (31.8 \pm 2.3 fruit/plant) (Table 3). Marketable fruit count for aquaculture effluent $(15.7 \pm 1.6$ fruit $/$ plant $)$ was not significantly higher $(P=0.070)$ than granular fertilizer $(10.3 \pm 1.3$ fruit/plant), and neither was different from fertigation (12.9 \pm 1.5 fruit/ plant) (Table 3 ). The marketable and nonmarketable proportion of fruit by count and nonmarketable counts were not significantly different (Table $3)$. The average numbers of undersized fruit were (mean \pm SE) $16.0 \pm$ $2.3,17.4 \pm 2.3$, and $14.1 \pm 2.3$ fruit/ plant, which were not significantly different for aquaculture effluent, fertigated, and granular fertilizer treatments, respectively.

Although total fruit yield in this study was within commercial ranges, irrigation regime could have affected production (Nemeskéri et al., 2019; Peet, 1992; Snyder, 2019). Nonmarketable fruit exhibited a variety of damage types including radial and concentric cracking, zipper scar, catfacing, splitting, discoloration, cold damage, insect damage, and animal damage. The most common issues were radial and concentric cracking, and especially discoloration due to cold damage in the final harvest. Fluctuating temperatures in the fall can produce small fruit due to high temperatures, and low temperatures can lead to misshapen fruit according to Snyder (2019). Variability in irrigation and precipitation is likely responsible for cracking issues (Kemble et al., 2004; Snyder, 2019; University of Georgia, 2017). The maximum air temperature was $96{ }^{\circ} \mathrm{F}$, while the minimum air temperatures was low as $47^{\circ} \mathrm{F}$ during the final 2 weeks of the study, exceeding the minimum recommended temperature of $50{ }^{\circ} \mathrm{F}$ (Bauer et al., 2009). The cold temperatures caused significant damage to the fruit, which greatly impacted the marketable yield. The experiment was ended earlier than anticipated because of freezing temperatures; therefore, many of the fruit from the final harvest were undersized. Typical fall transplant in the southeastern United States occurs in late July

Table 2. Average total, marketable, and nonmarketable fruit yield per plant by weight for 'Celebrity' tomato grown in raised beds under three nutrient management regimes.

\begin{tabular}{|c|c|c|c|c|c|}
\hline \multirow[b]{2}{*}{ Treatment } & \multirow{2}{*}{$\frac{\text { Total yield }}{\text { Fruit wt }(\mathrm{g})^{\mathrm{z}}}$} & \multicolumn{2}{|c|}{ Marketable yield } & \multicolumn{2}{|c|}{ Nonmarketable yield } \\
\hline & & Fruit wt (g) & Proportion by wt (\%) & Fruit wt (g) & Proportion by wt (\%) \\
\hline Effluent & $4,709.7 \mathrm{a}^{\mathrm{y}}$ & $2,319.8 \mathrm{a}$ & 48.9 & $2,389.9 \mathrm{a}$ & 51.1 \\
\hline Granular & $3,448.7 \mathrm{~b}$ & $1,462.7 \mathrm{~b}$ & 42.3 & $1,985.9 \mathrm{a}$ & 57.7 \\
\hline
\end{tabular}

${ }^{\mathrm{z}} 1 \mathrm{~g}=0.0353 \mathrm{oz}$.

${ }^{\mathrm{y}}$ Means with different lowercase letters within columns are statistically different by the Holm-Tukey method $(\alpha=0.05)$.

Table 3. Average total fruit count per plant for 'Celebrity' tomato grown in raised beds under three nutrient management regimes.

\begin{tabular}{|c|c|c|c|c|c|}
\hline \multirow[b]{2}{*}{ Treatment } & \multirow{2}{*}{$\frac{\text { Total yield }}{\text { Fruit (no.) }}$} & \multicolumn{2}{|c|}{ Marketable yield } & \multicolumn{2}{|c|}{ Nonmarketable yield } \\
\hline & & Fruit (no.) & Proportion by no. (\%) & Fruit (no.) & Proportion by no. (\%) \\
\hline Effluent & 41.0 & 15.7 & 38.3 & 25.2 & 61.7 \\
\hline Granular & 31.8 & 10.3 & 32.3 & 21.5 & 67.7 \\
\hline
\end{tabular}


(Boyhan et al., 2014). Transplanting 2 to 4 weeks earlier could have improved the size and quality of tomatoes harvested. An average of $15.8 \pm$ 4.5 undersized fruit were harvested per plant, with an average combined weight of $736.5 \pm 192.6 \mathrm{~g}$ per plant. If the growing period had been extended by 1 month to allow the fruit to mature, the total fruit yield, especially weight harvested, would have been much higher (Boyhan et al., 2014; Masabni et al., 2016). Additionally, lack of water, high temperatures, and shading could have led to undersized fruit (Snyder, 2019).

LEAF GREENNESS (SPAD). The average leaf greenness (SPAD) measurements were (mean \pm SE) $54.5 \pm$ $0.9,55.4 \pm 0.9$, and $56.7 \pm 0.9$, which were not significantly different $(P \geq$ 0.184 ) for aquaculture effluent, fertigated, and granular fertilizer treatments, respectively. SPAD measurements observed were within the range of 48.6 to 56.7 described by Nemeskéri et al. (2019). They demonstrated that irrigation regime has a significant effect on SPAD as the plant matures into the early fruit development stage, with decreasing SPAD measurements occurring with increasing irrigation frequency. This was related to higher canopy temperature causing chlorophyll degradation in dry conditions, and thus leading to greater reflectance and greater SPAD readings. Additionally, SPAD measurements were positively correlated with individual fruit weight, total yield, and marketable yield. The lowest SPAD readings in this study were found in the aquaculture effluent treatment, and the highest were in the granular fertilizer treatment, which is consistent with the correlations described by Nemeskéri et al. (2019).

SOIL FERTILITY, IRRIGATION, AND FOLIAR ANALYSIs. Average pretransplant $\mathrm{N}, \mathrm{P}$, and $\mathrm{K}$ levels across all treatments were 110,235 , and 233 $\mathrm{lb} / \mathrm{acre}$, respectively. Due to leaks in the irrigation system, the exact amount of water applied is unknown. It was assumed that $90 \mathrm{gal}$ of irrigation water per raised bed was applied. The cumulative rainfall during the study period was 4.2 inches, or $\approx 208$ gal per raised bed, for a combined water provision of $298 \mathrm{gal}$ per raised bed, or $18.6 \mathrm{gal} / \mathrm{plant}$. The recommended watering rate for tomato plants is 1 to 1.5 inches of water per week (University of Georgia, 2017), which would equate to 534 to 801 gal of water per raised bed, which is more than the approximated 298 gal per raised bed applied. Although these levels are lower than the recommended levels for tomato, the plants did not show signs of water stress during the culture period. Based on average aquaculture effluent nutrient concentrations measured at the beginning of the experiment, the approximate fertility applied in $\mathrm{lb} /$ acre was $144.4 \mathrm{~N}, 239 \mathrm{P}, 289.6 \mathrm{~K}, 263.9$ $\mathrm{Mg}, 1,906.3 \mathrm{Ca}, 55.8 \mathrm{~S}, 1.1 \mathrm{~B}, 10.3$ $\mathrm{Zn}, 23.0 \mathrm{Mn}, 23.0 \mathrm{Fe}$, and $1.3 \mathrm{Cu}$.

The foliar analysis (Table 4 ) revealed that all nutrient concentrations were sufficient for tomato production (Campbell, 2013; Hochmuth et al., 2018;
McMurtry et al., 1990), with some nutrient concentrations higher than the target range (Maynard and Hochmuth, 2007). Significant differences in foliar nutrient concentration were found for sulfur $(P=0.044)$ and copper $(P=0.002)$, with aquaculture effluent being lower than conventional fertigation (Table 4). Similarly, foliar concentrations were significantly lower in aquaculture effluent than granular fertilizer treatments for sulfur $(P=0.030)$ and copper $(P=$ 0.004 ) (Table 4). Foliar N, P, K, Mg, $\mathrm{Ca}, \mathrm{B}, \mathrm{Zn}, \mathrm{Mn}$, and Fe concentrations were not significantly different among treatments (Table 4).

The target $\mathrm{N}$ application for this study was 180 to $200 \mathrm{lb} / \mathrm{acre}$, but approximated $\mathrm{N}$ was $144 \mathrm{lb} /$ acre in the aquaculture effluent treatment. However, $\mathrm{N}$ deficiencies were not experienced in this study. The foliar $\mathrm{N}$ content was $\approx 4.1 \%$ across treatments, which is within the sufficiency range (Campbell, 2013; Hochmuth et al., 2018). Pinto et al. (1997) evaluated the use of $\mathrm{N}$ in fertigation of tomato plants, finding significant differences in fruit size and overall yield with $\mathrm{N}$ levels less than $80 \mathrm{lb} /$ acre. Fertigation can increase tomato yield by around $20 \%$ compared with conventional fertilization (Pinto et al., 1997). This is like our results, where fertigation increased total weight yield by $32.2 \%$ and aquaculture effluent increased yield by $36.5 \%$.

Phosphorus levels averaged 235 $\mathrm{lb} / \mathrm{acre}$, which exceeds the recommended rates of $200 \mathrm{lb} /$ acre $($ Kemble

Table 4. The average foliar nutrient concentration in newly matured tomato leaflets of 'Celebrity' tomato grown in raised beds under three nutrient management regimes. ${ }^{\mathrm{z}}$

\begin{tabular}{|c|c|c|c|c|c|}
\hline \multirow[b]{2}{*}{ Nutrient } & \multicolumn{5}{|c|}{ Treatment } \\
\hline & Unit $^{\mathrm{y}}$ & Aquaculture effluent & Conventional fertigation & Granular fertilizer & Sufficiency range $^{\mathrm{x}}$ \\
\hline Nitrogen & $\%$ & $4.10^{\mathrm{w}}$ & 4.12 & 4.15 & $2-3$ \\
\hline Potassium & $\%$ & 3.75 & 3.80 & 3.58 & $1.5-2.5$ \\
\hline Magnesium & $\%$ & 0.67 & 0.78 & 0.83 & $0.25-0.5$ \\
\hline Calcium & $\%$ & 4.23 & 4.42 & 4.46 & $1-2$ \\
\hline Zinc & ppm & 19.50 & 22.67 & 20.83 & $20-40$ \\
\hline Manganese & ppm & 40.33 & 40.33 & 44.17 & $30-100$ \\
\hline Iron & ppm & 161.50 & 162.17 & 165.83 & $40-100$ \\
\hline Copper & ppm & $12.67 \mathrm{a}$ & $17.33 \mathrm{~b}$ & $16.83 \mathrm{c}$ & $5-10$ \\
\hline
\end{tabular}

${ }^{\mathrm{z}}$ Foliar nutrient analysis was conducted by Water's Laboratory (Camilla, GA).

${ }^{\mathrm{y}} \mathrm{l} \mathrm{ppm}=1 \mathrm{mg} \cdot \mathrm{kg}^{-1}$.

${ }^{\mathrm{x}}$ Nutrient concentration in most recently matured leaf during harvest period (Maynard and Hochmuth, 2007).

wold text indicates levels above the sufficiency range.

${ }^{\mathrm{v}}$ Means within the same row followed by a different letter denotes a statistical difference between treatments according to the Holm-Tukey method $(\alpha=0.05)$. 
et al., 2004) and $120 \mathrm{lb} /$ acre (Maynard and Hochmuth, 2007). Phosphorus levels greater than $1 \% \mathrm{P}$ in plant tissues can cause interveinal necrosis and reddening or burning of leaf margins, especially for container and hydroponic growers (Jones, 1998). However, soil farmers tend not to observe issues with $\mathrm{P}$ toxicity (Jones, 1998). The $\mathrm{P}$ levels in the foliar analysis were $\approx 0.35 \%$, which is in the recommended range (Campbell, 2013; Hochmuth et al., 2018).

Calcium levels were initially high $(1702.5 \mathrm{lb} / \mathrm{acre})$ in all raised beds because of previous fertilizer applications from prior studies. Calcium concentration in the aquaculture effluent averaged $113 \mathrm{mg} \cdot \mathrm{L}^{-1}$, which came mostly from $\mathrm{Ca}(\mathrm{OH})_{2}$ that was added to the fish tank to raise $\mathrm{pH}$. Excessive Ca does not have apparent toxicity symptoms but may cause issues with the availability of other nutrients such as $\mathrm{S}, \mathrm{Mg}$, and $\mathrm{K}$ (Resh, 2013). Lower levels of $S$ in the leaf tissues may have been related to excessive $\mathrm{Ca}$ levels in the aquaculture effluent and soil.

Manganese levels were calculated at $23 \mathrm{lb} /$ acre, which is lower than the recommended 31 to $40 \mathrm{lb} /$ acre; however foliar analysis revealed that $\mathrm{Mn}$ levels were 40 to $44 \mathrm{ppm}$, exceeding the minimum level of 30 ppm (Campbell, 2013; Hochmuth et al., 2018). Average foliar concentrations for $\mathrm{S}, \mathrm{Cu}, \mathrm{K}, \mathrm{Mg}$, and $\mathrm{Fe}$ (Table 4) also exceeded the sufficiency range (Campbell, 2013; Hochmuth et al., 2018; Maynard and Hochmuth, 2007).

The results of this study indicate that tomato production in raised beds using aquaculture effluent as a nutrient source and water supplement along with commercially recommended pre-application of nutrients is feasible, with yields like conventional fertilizer practices. Differences in foliar analysis merit investigation into the mechanisms of nutrient uptake and availability between production methods. Further exploration into viable crops and commercially viable production technology such as plasticulture should be pursued. The use of aquaculture effluent for vegetable production could alleviate some of the negative impacts of aquaculture on receiving waterbodies (Boyd and Hargreaves, 2004; Boyd and Tucker, 1998). This could contribute to the growth of the U.S. aquaculture industry and reduce the seafood trade deficit (FAO, 2018), thereby increasing aquaculture sustainability (Weeks, 2013).

\section{Literature cited}

Bauer, M., D.L. Barney, and J.A. Robbins. 2009. Growing tomatoes in cool, short-season locations. Univ. Idaho Ext. Bul. 864.

Blanchard, C., D.E. Wells, J.M. Pickens, and D.M. Blersch. 2020. Effect of pH on cucumber growth and nutrient availability in a decoupled aquaponic system with minimal solids removal. Horticulturae $6: 1-12$.

Boyd, C.E. and J.A. Hargreaves. 2004. Environmental issues, p. 634-657. In: C.S. Tucker and J.A. Hargreaves (eds.). Biology and culture of channel catfish. Elsevier, San Diego, CA.

Boyd, C.E. and C.S. Tucker. 1998. Pond aquaculture water quality management. Kluwer Academic Publ., Boston, MA.

Boyhan, G.E., S. Tate, R. McNeill, and J. McConnaughey. 2014. Evaluation of tomato varieties under organic production practices in Georgia. HortTechnology 24:252-258.

Campbell, C.R. 2013. Reference sufficiency ranges for plant analysis in the southern region of the United States. Southern Coop. Ser. Bul. 394.

Cantliffe, D.J. and J.J. Vansickle. 2001. Competitiveness of the Spanish and Dutch greenhouse industries with the Florida fresh vegetable industry. Proc. Florida State Hort. Soc. 114:283-287.

Castro, R.S., C.M.S.B. Azevedo, and F. Bezerra-Neto. 2006. Increasing cherry tomato yield using fish effluent as irrigation water in northeast Brazil. Scientia Hort. 110:44-50.

Danaher, J.J., J.M. Pickens, J.L. Sibley, J.A. Chappell, T.R. Hanson, and C.E. Boyd. 2013. Petunia growth response to container substrate amended with dewatered aquaculture effluent. HortTechnology 23:57-63.

Danaher, J.J., J.M. Pickens, J.L. Sibley, J.A. Chappell, T.R. Hanson, and C.E. Boyd. 2016. Tomato seedling growth response to different water sources and a substrate partially replaced with dewatered aquaculture effluent. Intl. J. Recycl. Org. Waste Agr. 5:25-32.

D'orbcastel, E.R. and J.P. Blancheton. 2006. The wastes from marine fish production systems: Characterization, mini- mization, treatment and valorization. World Aqua. Soc. Mag. 70:28-35.

Engindeniz, S. and A. Gül. 2009. Economic analysis of soilless and soil-based greenhouse cucumber production in Turkey. Sci. Agr. 66:606-614.

FAO, Food and Agriculture Organization of the United Nations. 2018. The state of world fisheries and aquaculture 2018Meeting the sustainable development goals. CC BY-NC-SA 3.0 IGO.

Fern, M.P. 2014. An economic comparison of three intensive fish production systems. MS Thesis, Auburn Univ., Auburn, AL. 22 June 2020. <http://hdl. handle.net/10415/4142>.

Graber, A. and R. Junge. 2009. Aquaponic systems: Nutrient recycling from fish wastewater by vegetable production. Desalination 246:147-156.

Hargreaves, J.A. and C.S. Tucker. 2004. Managing ammonia in fish ponds. Southern Reg. Aquaculture Ctr. Publ. 4603.

Hochmuth, G.J. and R.C. Hochmuth. 2018. Nutrient solution formulation for hydroponic (perlite, rockwool, NFT) tomatoes in Florida. Univ. Florida. Ext. Publ. HS796.

Hochmuth, G., D. Maynard, C. Vavrina, E. Hanlon, and E. Simonne. 2018. Plant tissue analysis and interpretation for vegetable crops in Florida. Univ. Florida, Inst. Food Agr. Sci. Ext. Publ. HS964.

Jones, J.B. 1998. Phosphorus toxicity in tomato plants: When and how does it occur? Commun. Soil Sci. Plant Anal. 29:1779-1784.

Jovicich, E., D.J. Cantliffe, E.H. Simonne, and P.J. Stoffella. 2007. Comparative water and fertilizer use efficiencies of two production systems for cucumbers. Acta Hort. 731:235-242.

Jovicich, E., J.J. VanSickle, D.J. Cantliffe, and P.J. Stoffella. 2005. Greenhousegrown colored peppers: A profitable alternative for vegetable production in Florida? HortTechnology 15:355-369.

Kemble, J.M., T.W. Tyson, and L.M. Curtis. 2004. Guide to commercial staked tomato production in Alabama. Alabama Coop. Ext. Serv. ANR-1156.

Khater, E.G., A.H. Bahnasawy, A.E.S. Shams, M.S. Hassaan, and Y.A. Hassan. 2015. Utilization of effluent fish farms in tomato cultivation. Ecol. Eng. 83:199207.

Masabni, J., Y. Sun, G. Niu, and P. Del Valle. 2016. Shade effect on growth and productivity of tomato and chili pepper. HortTechnology 26:334-350. 
Mariscal-Lagarda, M.M., F. Páez-Osuna, J.L. Esquer-Méndez, I. Guerrero-Monroy, A.R. del Vivar, and R. Félix-Gastelum. 2012. Integrated culture of white shrimp (Litopenaeus vannamei) and tomato (Lycopersicon esculentum Mill) with low salinity groundwater: Management and production. Aquaculture 366367:76-84.

Maynard, D.N. and G.J. Hochmuth. 2007. Knott's handbook for vegetable growers. 5th ed. Wiley, Hoboken, NJ.

McMurtry, M.R., P.V. Nelson, D.C. Sanders, and L. Hodges. 1990. Sand culture of vegetables using recirculated aquacultural effluents. Appl. Agr. Res. 5:280-284.

Monsees, H., W. Kloas, and S. Wuertz. 2017. Decoupled systems on trial: Eliminating bottlenecks to improve aquaponic processes. PLoS One 12:e0183056.

Nemeskéri, E., A. Neményi, A. Bocs, Z. Pék, and L. Helyes. 2019. Physiological factors and their relationship with the productivity of processing tomato under different water supplies. MDPI Water 11:586.

Nozzi, V., A. Graber, Z. Schmautz, A. Mathis, and R. Junge. 2018. Nutrient management in aquaponics: Comparison of three approaches for cultivating lettuce, mint and mushroom herb. MDPI Agron. $8: 27$.

Palada, M.C., W.M. Cole, and S.M.A. Crossman. 1999. Influence of effluents from intensive aquaculture and sludge on growth and yield of bell pepper. J. Sust. Agr. 14:85-103.

Pattillo, D.A. 2017a. An overview of aquaponic systems: Hydroponic components. North Central Reg. Aquaculture Ctr. Tech. Bul. 123.

Pattillo, D.A. 2017b. An overview of aquaponic systems: Aquaculture compo- nents. North Central Reg. Aquaculture Ctr. Tech. Bul. 124.

Peet, M.M. 1992. Fruit cracking in tomato. Hort Technology 2:216-223.

Pickens, J. 2015. Integrating effluent from recirculating aquaculture systems with greenhouse cucumber and tomato production. PhD Diss., Auburn Univ., Auburn, AL. 22 June 2020. <http://hdl. handle.net/10415/4782>.

Pickens, J.M., J. Danaher, and D. Wells. 2016. Greenhouse crops and cropping systems for commercial aquaponics. Southern Reg. Aquaculture Ctr. Publ. 5009 .

Pickens, J.M. and J. Danaher. 2016. Controlling the greenhouse environment for aquaponics. Southern Reg. Aquaculture Ctr. Publ. 5008.

Pinto, J.M., J.M. Soares, N.D. Costa, C.M.B. Faria, L.T. de L. Brito, and D.J. Silva. 1997. Doses e períodos de aplicação de nitrogênio via água de irrigação na cultura do tomate. Hortic. Bras. 15:1518.

Popma, T. and M. Masser. 1999. Tilapia: Life history and biology. Southern Reg. Aquaculture Ctr. Publ. 283.

Rafiee, G. and C.R. Saad. 2005. Nutrient cycle and sludge production during different stages of red tilapia (Oreochromis $s p$.) growth in a recirculating aquaculture system. Aquaculture 244:109-118.

Rakocy, J.E., R.C. Shultz, D.S. Bailey, and E.S. Thoman. 2004. Aquaponic production of tilapia and basil: Comparing batch and staggered cropping system. Acta Hort. 648:63-69.

Rakocy, J.E., M.P. Masser, and T.M. Losordo. 2006. Recirculating aquaculture tank production systems: AquaponicsIntegrating fish and plant culture. SRAC Publ. 0454.

Reinemann, D.J., J.Y. Parlange, and M.B. Timmons. 1990. Theory of small-diameter airlift pumps. Intl. J. Multiph. Flow 16:113-122.

Resh, H.M. 2013. Hydroponic food production. 7th ed. CRC Press, Boca Raton, FL.

Snyder, R. 2019. Tomato troubles: Common problems with tomatoes. Mississippi State Univ. Ext. Pub. 2975.

Sparks, A.N and D.G. Riley. 2019. Georgia pest management handbook, 2019 Commercial edition, Vegetables: Commercial vegetable insect control. Univ. Georgia Ext. Spec. Bul. 28.

Timmons, M.B. and J.M. Ebeling. 2013. Recirculating aquaculture. 3rd ed. Ithaca Publ., Ithaca, NY.

Tindall, J.A., R.B. Beverly, and D.E. Radcliffe. 1991. Mulch effect on soil properties and tomato growth using micro-irrigation. Agron. J. 83:1028-1034.

Tyson, R.V., D.D. Treadwell, and E.H. Simonne. 2011. Opportunities and challenges to sustainability in aquaponic systems. Hort Technology 21:6-13.

University of Georgia. 2017. Commercial tomato production handbook. Univ. Georgia Ext. Bul. 1312.

U.S. Department of Agriculture. 1997. United States standards for grades of fresh tomatoes. 20 May 2020. <https://www. ams.usda.gov/sites/default/files/ media/Tomato_Standard\%5B 1\%5D. $\mathrm{pdf}>$.

U.S. Environmental Protection Agency. 2020. National pollutant discharge elimination system aquaculture permitting. 20 May 2020. <https://www.epa.gov/ npdes/npdes-aquaculture-permitting $>$.

Weeks, C. 2013. Sustainable aquaculture in the North Central Region U.S.-A review of perceptions and recommendations from the aquaculture community. J. Ext. 51(2): commentary. 26 June 2020. <https://joe.org/joe/2013april/ comml.php>.

Yeo, S.E., F.P. Binkowski, and J.E. Morris. 2004. Aquaculture effluents and waste byproducts characteristics, potential recovery, and beneficial reuse. North Central Reg. Aquaculture Ctr. Tech. Bul. 119. 